\title{
INVENTARISASI EMISI SUMBER BERGERAK DARI TRANSPORTASI LAUT (NON-ROAD) DI WILAYAH PESISIR KOTA DENPASAR
}

\author{
Desak Putu Risky V.A ${ }^{1 *}$, I Wayan Arthana ${ }^{1}$, I Wayan Budiarsa Suyasa ${ }^{1}$ \\ ${ }^{1}$ Program Studi Magister Ilmu Lingkungan Universitas Udayana Bali \\ *Email : riskyvidika@gmail.com
}

\begin{abstract}
The development of marine transportation in Denpasar City followed by increasing number of visiting tourists who came to Denpasar City. This situation will contribute to air pollution problems. The purpose of this study was to determine the emission load produced by sea transportation in Denpasar City and the distribution of emissions gases such as $\mathrm{NO}_{\mathrm{x}}, \mathrm{SO}_{\mathrm{x}}, \mathrm{HC}, \mathrm{PM}_{10}, \mathrm{CO}$ and $\mathrm{CO}_{2}$. Emission load calculations based on the guidelines of the EMEP Corinair Guidebook using Tier 3, which the emission factors used refer to the CORINAIR GB 2013 1.A.3.d.

The results showed a total emission load from non-road mobile sources of marine transportation in the Denpasar city such as NOx is 14,583.69 tons/year, SOx by 85.49 tons/year, HC by 746.05 tons/year, $\mathrm{PM}_{10}$ at 503.53 tons/year, $\mathrm{CO}$ at 123,123.58 tons/year, and $\mathrm{CO}_{2}$ of 1,457,909.95 tons/year. Distribution of the source of pollutants mapped using GIS (Geographic Information System) shows that the emission load of $\mathrm{NO}_{\mathrm{x}}, \mathrm{SO}_{\mathrm{x}}, \mathrm{HC}$ and $\mathrm{PM}_{10}$ are likely identical, which mostly distributed around Benoa Port, but $\mathrm{CO}_{2}$ and $\mathrm{CO}$ have different patterns. The pattern of distribution of $\mathrm{NO}_{\mathrm{x}}, \mathrm{SO}_{\mathrm{x}}, \mathrm{HC}$, and $\mathrm{PM}_{10}$ with the highest intensity follows the contours of the ships from Benoa Port. $\mathrm{CO}$ gas distribution pattern follows the contours of the ship from the Serangan Port and Sanur Port, $\mathrm{CO}_{2}$ gas distribution pattern almost evenly in almost all flow well from the Serangan Port, Sanur Port and Benoa Port.
\end{abstract}

Keywords : Denpasar City, Emission Load, Benoa Port, Sanur Port, Serangan Port, Air Pollution.

\section{PENDAHULUAN}

Kota Denpasar juga merupakan kota yang cukup terkenal dalam wisata pantainya, khususnya wilayah Denpasar Selatan. Peraturan Daerah Provinsi Bali Nomor 16 Tahun 2009 menyatakan bahwa kawasan strategis pariwisata di Kota Denpasar adalah Pantai Sanur dan Pulau Serangan sebagai kawasan lindung terumbu karang di Kota Denpasar. Wisata pantai tidak hanya mengandalkan pemandangan indah sebagai daya tariknya, namun dengan adanya kegiatan water sport serta paket-paket wisata lainnya akan menambah ketertarikan wisatawan lokal maupun internasional untuk datang berlibur. Pantai Sanur merupakan pantai yang dikembangkan menjadi pelabuhan kecil untuk kapal cepat menuju ke Nusa Penida, Jungut Batu dan Lembongan. Aktivitas penduduk yang sering melakukan kegiatan persembahyangan ke Nusa Penida dan berwisata ke Lembongan dan Jungut Batu menambah padat lalu lintas transportasi laut di Pelabuhan Sanur.Pulau Serangan merupakan daerah tujuan wisata yang terletak di Kota Denpasar. Lokasi pulau ini sangat strategis yaitu dikelilingi destinasi wisata utamaTanjung Benoa, dan Pulau Gili Trawangan yang berada di Lombok sehingga banyak terdapat transportasi laut yang menghubungkan Pulau Serangan dengan daerah di sekitarnya sedangkan Pelabuhan Benoa merupakan dermaga tempat bersandar berbagai jenis kapal seperti kapal penumpang, kapal ikan dan beberapa jenis transportasi laut lainnya.

Perkembangan transportasi laut seiring dengan banyaknya wisatawan yang datang akan berkontribusi pada emisi gas buang dari kapal-kapal dan berbagai jenis alat transportasi laut lainnya. Inventarisasi emisi adalah pencatatan secara komprehensif tentang beban emisi dari sumbersumber pencemar udara dalam satu wilayah untuk satu periode tertentu. Melalui inventarisasi emisi ini sumber-sumber pencemar udara dapat diidentifikasi berdasarkan sumbernya, sehingga rencana aksi yang disusun juga bisa sesuai dengan targetbeban emisi dari sumber mana yang akan diturunkan (KLH, 2013). Berdasarkan permasalahan di atas, maka direncanakan penelitian untuk menghitung beban emisi pencemar udara dan sebaran emisi dari sumber bergerak dari transportasi laut (Non Road) Kota Denpasar yang meliputi pencemar $\mathrm{NO}_{\mathrm{x}}, \mathrm{SO}_{\mathrm{x}, \mathrm{HC}}$ $\mathrm{PM}_{10}$, $\mathrm{CO}$ dan $\mathrm{CO}_{2}$.

\section{METODOLOGI}

Lokasi penelitian meliputi pelabuhan-pelabuhan yang berada di Kota Denpasar yaitu Pelabuhan Benoa, Pelabuhan Sanur, dan Pelabuhan Serangan. Penelitian dilakukan pada bulan April sampai dengan Juni 2014. 
Sumber data yang digunakan dalam penelitian adalah data primer dan data sekunder. Data primer didapatkan melalui survey lapangan yang meliputi data mengenai jenis dan jumlah kapal, rute kapal, jarak dan waktu tempuh kapal, spesifikasi mesin kapal, jenis bahan bakar dan jumlah penggunaan bahan bakar dan kapasistas kapal. Survey dilakukan di Pelabuhan Sanur dan Pelabuhan Serangan. Data Sekunder diperoleh dari instansi yang terkait yaitu Kantor Kesyahbandaran dandan Otoritas Pelabuhan Benoa dan Pos Syahbandar Sanur.

Setelah data terkumpul, dilakukan perhitungan total beban emisi. Perhitungan dilakukan dengan menggunakan pendekatan beban emisi sebagai berikut :

Penentuan Konsumsi bahan bakar diestimasikan sebagai

$\mathrm{FCh}=(\mathrm{P} \times \mathrm{MCR} \times \mathrm{SFC}) / 1000$

$\mathrm{FC}=\mathrm{N} \times \mathrm{FCh} \times 2(\mathrm{~L} / 1000 \mathrm{~V})$

Dimana :

FCh : Konsumsi bahan bakar per kapal (kg/jam)

$\mathrm{P} \quad$ : Tenaga mesin $(\mathrm{kW})$

MCR : \% Maximum Continous Rating

SFC : Spesific Fuel Consumption (g fuel $/ \mathrm{kWh}$ )

FC : Konsumsi bahan bakar (Ton/tahun)

$\mathrm{N}$ : Jumlah kapal dalam setahun

L : Jarak tempuh $(\mathrm{km})$

V : Kecepatan kapal (km/jam)

Jarak tempuh yang dihitung hanya pada Kota Denpasar, menurut Undang-Undang Nomor 22 Tahun 1999 Pasal 10 Ayat 3, penataan ruang wilayah Kabupaten/Kota mencakup wilayah laut sampai dengan batas 4 mil atau sepertiga wilayah laut Provinsi, sehingga di asumsikan jarak tempuh kapal yang dihitung adalah dalam kawasan kota Denpasar adalah 4 mil. Jarak tempuh kapal dari masingmasing Pelabuhan diukur dengan menggunakan GIS setelah alur kapal ditentukan.

Untuk memperkirakan emisi dari perahuperahu kecil, dimana data mengenai mode operasi kapal tidak bisa ditentukan, maka dapat digunakan Persamaan (4.7) yang didasarkan pada data jenis kapal, jenis bahan bakar, tipe mesin, technology layer, engine load factor dan estimasi waktu operasi kapal selama setahun (Trozzi \& Riccardo, 2013).

$E_{i, m}=\sum_{b} \sum_{e} \sum_{z}\left[N_{b, e, z} \times T_{b, e, z} \times P_{b, e, z} \times\left[F_{b, e, z} \times E_{b, e, z}\right](3)\right.$

\section{Dimana :}

Ei,m : Jumlah emisi total (ton)

$\mathrm{N}$ : Jumlah kapal

$\mathrm{T}$ : Waktu rata-rata operasi dari masingmasing kapal per tahun (jam/kapal)

$\mathrm{P} \quad$ : Tenaga mesin $(\mathrm{kW})$

EF : Factor emisi (kg/ton) (Lampiran 3)

LF : Engine Load factor (\%)
Sehingga total beban emisi Kota Denpasar dari transportasi laut:

Total Beban Emisi = Emisi di Pelabuhan Benoa (ton/tahun)

+ Emisi di Pelabuhan Sanur + Emisi di Pelabuhan Serangan

Analisis emisi di wilayah Kota Denpasar menggunakan GIS, oleh karena itu, wilayah pesisir Kota Denpasar dibagi menjadi grid-grid, yang didasarkan atas luas Kota Denpasar $127,78 \mathrm{~km}^{2}$, sehingga dipergunakan grid 1 x $1 \mathrm{~km}$ seperti yang ditunjukkan pada Gambar 1.

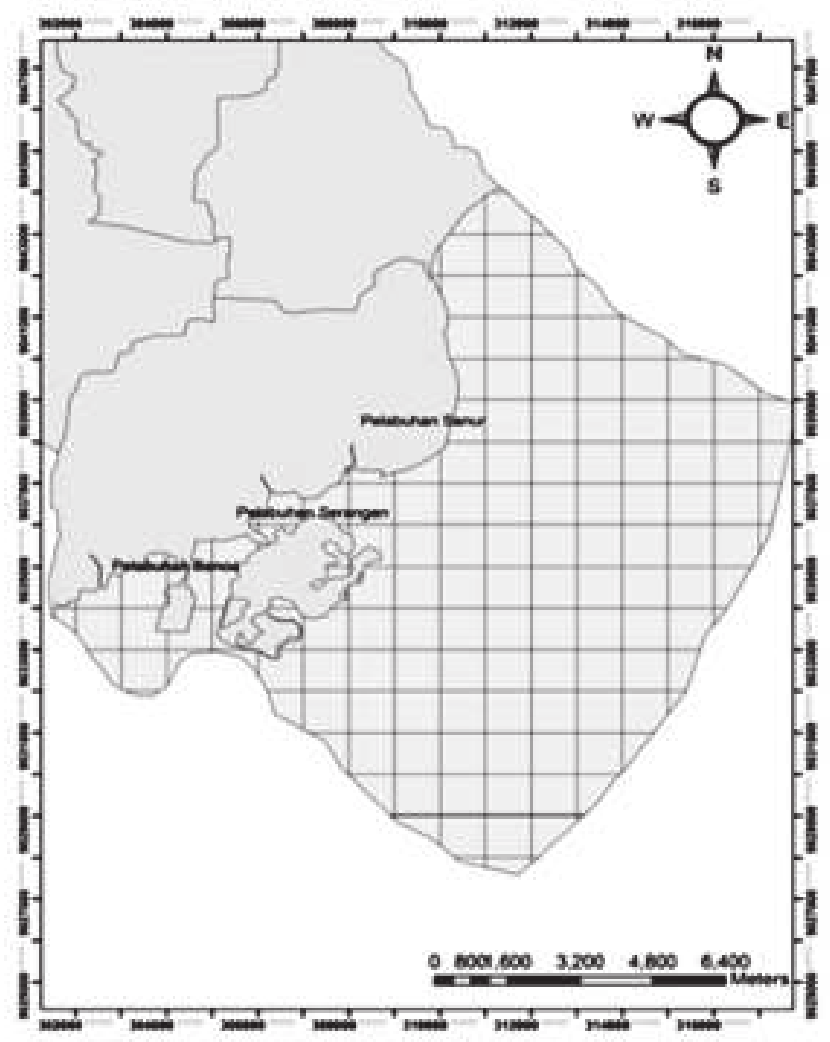

Gambar 1. Pembagian grid daerah pesisir Kota Denpasar

\section{HASIL}

\subsection{Perhitungan Beban Emisi di Pelabuhan Benoa}

Pelabuhan Benoa merupakan Pelabuhan Internasional yang banyak disinggahi oleh berbagai jenis kapal, baik dari dalam negeri maupun luar negeri, sehingga dilakukan pengelompokkan jenis transportasi laut. Jenis kapal yang beraktivitas di 
Tabel 1. Total emisi di Pelabuhan Benoa menurut jenis kapal

\begin{tabular}{|c|c|c|c|c|c|c|}
\hline \multirow{2}{*}{ JENIS KAPAL } & \multicolumn{6}{|c|}{ EMISSION LOAD (Ton/Tahun) } \\
\hline & $\mathrm{NO}_{\mathrm{x}}$ & $\mathrm{SO}_{\mathrm{x}}$ & $\mathrm{HC}$ & $\mathrm{PM}_{10}$ & $\mathrm{CO}$ & $\mathrm{CO}_{2}$ \\
\hline Tug Boat & 388,132 & 2,375 & 12,870 & 11,211 & 58,578 & $24.646,034$ \\
\hline Tanker & 115,494 & 0,611 & 6,363 & 4,110 & 15,073 & $6.341,938$ \\
\hline General Cargo & 24,375 & 0,129 & 1,388 & 0,890 & 3,193 & $1.343,517$ \\
\hline Container & 0,111 & 0,001 & 0,006 & 0,004 & 0,015 & 6,110 \\
\hline Passanger (G) & 1,698 & 0,003 & 2,139 & 0,014 & 97,445 & 494,389 \\
\hline Passanger (MDO) & $10.029,862$ & 53,382 & 581,957 & 371,226 & $1.316,750$ & $554.004,953$ \\
\hline Fishing $(G)$ & 0,305 & 0,001 & 0,371 & 0,005 & 17,450 & 88,533 \\
\hline Fishing (MDO) & $3.995,811$ & 24,610 & 135,432 & 115,245 & 607,045 & $255.405,891$ \\
\hline Others & 25,799 & 0,159 & 0,872 & 0,805 & 3,916 & $1.647,707$ \\
\hline TOTAL & $14.581,588$ & 81,270 & 741,400 & 503,510 & $2.119,466$ & $843.979,073$ \\
\hline
\end{tabular}

Tabel 2. Hasil perhitungan Emisi di Pelabuhan Benoa sesuai mode operasi kapal

\begin{tabular}{lrrrrrr}
\hline \multirow{2}{*}{ Mode Operasi } & \multicolumn{7}{c}{ Total Emisi (Ton/Tahun) } \\
\cline { 2 - 7 } & NOx & SOx & HC & PM10 & C O & CO $_{2}$ \\
\hline Hotelling & $2.157,38$ & 14,05 & 199,07 & 150,08 & 366,94 & $145.906,14$ \\
Manoevring & $2.342,68$ & 15,10 & 205,37 & 154,98 & 392,67 & $156.799,24$ \\
Cruising & $10.081,53$ & 52,12 & 336,96 & 198,45 & $1.359,86$ & $541.273,69$ \\
\hline
\end{tabular}

Pelabuhan Benoa dibagi menjadi beberapa jenis, antara lain Tug Boat, Tanker, General Cargo, Passanger, Fishing ship dan Others. Kapal-kapal yang dikelompokkan dalam kategori Others adalah Survey Vessel, Landing Craft, Research Vessel, dan Utility Vessel.

Jenis kapal passanger dan fishing dikelompokkan kembali menjadi 2 yang disimbolkan menjadi Passanger (G), Passanger (MDO), Fishing (G) dan Fishing (MDO). Pengelompokkan ini didasarkan oleh perbedaan bahan bakar yang digunakan oleh kapal. Simbol (G) digunakan untuk kapal berbahan bakar Gasoline dan symbol (MDO) digunakan untuk kapal berbahan bakar Marine Diesel Oil. Kapal dengan bahan bakar Gasoline secara umum adalah kapal ber-GT kecil.Perhitungan beban emisi di Pelabuhan benoa dapat juga disajikan berdasarkan mode operasional kapal, seperti yang ditunjukkan pada Tabel 1.

Berdasarkan Tabel 1dapat dilihat bahwa jenis kapal Passanger MDO merupakan penyumbang emisi tertinggi untuk semua jenis pencemar yaitu 10.029,862 ton/tahun untuk NO , 53,382 ton/tahun untuk $\mathrm{SO}_{\mathrm{x}}, 581,957$ ton/tahun untuk $\mathrm{HC}, 371,226$ ton/tahun untuk $\mathrm{PM}_{10}, 1.316,750$ ton/tahun untuk CO dan 554.004,953 ton/tahun untuk CO2 sedangkan jenis kapal container merupakan penyumbang emisi terkecil untuk semua jenis pencemar yaitu untuk pencemar $\mathrm{NO}_{\mathrm{x}}$ sebesar 0,111 ton/tahun, $\mathrm{SO}_{\mathrm{x}}$ sebesar 0,001 ton/tahun, $\mathrm{HC}$ sebesar 0,006 ton/tahun, $\mathrm{PM}_{10}$ sebesar 0,004 ton/tahun, CO sebesar 0,015 ton/tahun dan $\mathrm{CO}_{2}$ sebesar 6,110 ton/tahun.
Tabel 2 menunjukkan emisi yang dihasilkan oleh kapal-kapal yang beraktivitas di Pelabuhan benoa yang disajikan berdasarkan mode operasi kapal. Mode cruising menghasilkan emisi terbanyak untuk semua parameter pencemar, sedangkan hotelling menghasilkan emisi paling sedikit diantara ketiga mode operasi tersebut.

\subsection{Perhitungan Beban Emisi di Pelabuhan Sanur}

Data volume lalu lintas di Pelabuhan Sanur didapatkan dari Pos Syahbandar Sanur. Jenis kapal yang ada di Pelabuhan Sanur secara keseluruhan adalah sama, yaitu speed boat sehingga tidak perlu dilakukan pengelompokkan jenis kapal.

Tabel 3. Volume lalu lintas di Pelabuhan Sanur Tahun 2013

\begin{tabular}{lc}
\hline Bulan & Jumlah Kapal \\
\hline Januari & 323 \\
Februari & 317 \\
Maret & 319 \\
April & 340 \\
Mei & 357 \\
Juni & 344 \\
Juli & 355 \\
Agustus & 361 \\
September & 344 \\
Oktober & 337 \\
November & 316 \\
Desember & 322 \\
Jumlah & 4.035 \\
\hline
\end{tabular}


Tabel 3 menunjukkan jumlah kapal yang beraktivitas di Pelabuhan Sanur per bulan selama tahun 2013, dimana aktivitas tertinggi terjadi di bulan Agustus yaitu sebanyak 361 kapal dan aktivitas terendah terjadi di bulan November yaitu sebanyak 316 kapal. Setelah dilakukan perhitungan total emisi di pelabuhan sanur, maka didapatkan hasil seperti yang ditunjukkan pada Tabel 4 .

\subsection{Perhitungan Beban Emisi di Pelabuhan Serangan}

Data volume di Pelabuhan Serangan didapatkan dengan melakukan survey terhadap perusahaan penyedia jasa pariwisata di Pulau Serangan terdiri dari 4 perusahaan antara lain Gili Getaway, Blue Water Express, PT. Eka Jaya dan Serangan Water Sport. Hasil perhitungan total emisi di Pelabuhan Serangan ditunjukkan pada Tabel 5.

Tabel 5 menunjukkan bahwa jumlah perjalanan masing-masing kapal adalah 1 trip/hari sedangkan, aktivitas lalu lintas kapal dihentikan pada saat Hari Raya Nyepi, sehingga dapat diasumsikan, dalam 1 tahun, masing-masing kapal berlayar sebanyak 364 kali.

\subsection{Beban Emisi Sumber Bergerak (Non-Road)} dari Transportasi Laut di Kota Denpasar

Total emisi transportasi laut di Kota Denpasar didapatkan dengan menjumlahkan beban emisi di tiga pelabuhan, yaitu Pelabuhan Benoa, Pelabuhan Sanur dan Pelabuhan Serangan seperti yang ditunjukkan pada Tabel 6 .

3.5. Distribusi Sebaran Sumber Emisi Pencemar $\mathrm{NO}_{\mathrm{x}}, \mathrm{SO}_{\mathrm{x}}, \mathrm{HC}, \mathrm{PM}_{10}, \mathrm{CO}$, dan $\mathrm{CO}_{2}$ dari Transportasi Lautdi Kota Denpasar Distribusi sebaran sumber emisi pencemar $\mathrm{NO}_{\mathrm{x}}$, $\mathrm{SO}_{\mathrm{x}}, \mathrm{HC}, \mathrm{PM}_{10}, \mathrm{CO}$, dan $\mathrm{CO}_{2}$ yang telah dihitung di Pelabuhan Sanur, Pelabuhan Serangan dan Pelabuhan Benoa kemudian divisualisasikan dengan menggunakan GIS. Alur kapal kemudian digambar di dalam peta sehingga dapat diukur jarak tempuh kapal dalam batas perairan Kota Denpasar. Dari hasil pengukuran jarak tempuh didapatkan bahwa rata-rata jarak tempuh kapal yang beroperasi di Pelabuhan Sanur adalah 7,53 km, Pelabuhan Serangan adalah 9,16 km dan jarak tempuh kapal yang beroperasi di Pelabuhan Benoa adalah sekitar $14,82 \mathrm{~km}$. Peta distribusi dibagi menjadi tujuh kelas

Tabel 4. Total Emisi di Pelabuhan Sanur

\begin{tabular}{lcccrrr}
\hline & \multicolumn{5}{c}{ Emisi (Ton/Tahun) } \\
\cline { 2 - 7 } Bulan & $\mathbf{N O}_{\mathbf{x}}$ & $\mathbf{S O}_{\mathbf{x}}$ & $\mathrm{HC}$ (NMVOC) & $\mathbf{P M}_{10}$ & $\mathbf{C O}$ & $\mathbf{C O}_{2}$ \\
\hline Januari & 0,0884 & 0,1768 & 0,1114 & 0,0007 & $5.074,2564$ & $25.744,9327$ \\
Februari & 0,0868 & 0,1735 & 0,1093 & 0,0007 & $4.979,9978$ & $25.266,6987$ \\
Maret & 0,0873 & 0,1746 & 0,1100 & 0,0007 & $5.011,4173$ & $25.426,1100$ \\
April & 0,0931 & 0,1861 & 0,1173 & 0,0007 & $5.341,3226$ & $27.099,9292$ \\
Mei & 0,0977 & 0,1954 & 0,4480 & 0,0008 & $5.608,3887$ & $28.454,9257$ \\
Juni & 0,0942 & 0,1883 & 0,1186 & 0,0008 & $5.404,1616$ & $27.418,7519$ \\
Juli & 0,0972 & 0,1944 & 0,1224 & 0,0008 & $5.576,9691$ & $28.295,5143$ \\
Agustus & 0,0988 & 0,1976 & 0,1245 & 0,0008 & $5.671,2278$ & $28.773,7484$ \\
September & 0,0942 & 0,1883 & 0,1186 & 0,0008 & $5.404,1616$ & $27.418,7519$ \\
Oktober & 0,0922 & 0,1845 & 0,9323 & 0,0007 & $5.294,1932$ & $26.860,8122$ \\
November & 0,0865 & 0,1730 & 0,1090 & 0,0007 & $4.964,2880$ & $25.186,9930$ \\
Desember & 0,0881 & 0,1763 & 0,1111 & 0,0007 & $5.058,5467$ & $25.665,2271$ \\
TOTAL & 1,1045 & 2,2091 & 2,5327 & 0,0088 & $63.388,9309$ & $321.612,3951$ \\
\hline
\end{tabular}

Tabel 5. Total emisi di Pelabuhan Serangan

\begin{tabular}{|c|c|c|c|c|c|c|}
\hline \multirow{2}{*}{ Nama Kapal } & \multicolumn{6}{|c|}{ Emisi (Ton/Tahun) } \\
\hline & $\mathrm{NO}_{\mathrm{x}}$ & $\mathrm{SO}_{\mathrm{x}}$ & HC (NMVOC) & $\mathrm{PM}_{10}$ & $\mathrm{CO}$ & $\mathrm{CO}_{2}$ \\
\hline Naruma & 0,19 & 0,37 & 0,24 & 0,001 & $10.734,70$ & $54.463,97$ \\
\hline Blue Water I & 0,16 & 0,32 & 0,21 & 0,001 & $9.349,58$ & $47.436,36$ \\
\hline Blue Water III & 0,22 & 0,45 & 0,28 & 0,002 & $12.881,64$ & $65.356,76$ \\
\hline Eka Jaya & 0,27 & 0,54 & 0,34 & 0,002 & $15.457,97$ & $78.428,11$ \\
\hline Inami NP & 0,16 & 0,32 & 1,06 & 0,001 & $9.349,58$ & $47.436,36$ \\
\hline TOTAL & 1,01 & 2.01 & 2,13 & 0,007 & $5.773,46$ & $293.121,55$ \\
\hline
\end{tabular}


Tabel 6. Total Beban Emisi Transportasi Laut di Kota Denpasar

\begin{tabular}{|c|c|c|c|c|c|c|}
\hline \multirow[t]{3}{*}{ PELABUHAN } & \multicolumn{5}{|c|}{ Gas Pencemar } & \\
\hline & & & & & \multicolumn{2}{|c|}{$\mathrm{HC}$} \\
\hline & $\begin{array}{l}\text { Beban Emisi } \\
\text { (Ton/tahun) }\end{array}$ & $\begin{array}{c}\text { Persentase } \\
(\%)\end{array}$ & $\begin{array}{l}\text { Beban Emisi } \\
\text { (Ton/tahun) }\end{array}$ & $\begin{array}{c}\text { Persentase } \\
(\%)\end{array}$ & $\begin{array}{l}\text { Beban Emisi } \\
\text { (Ton/tahun) }\end{array}$ & $\begin{array}{c}\text { Persentase } \\
(\%)\end{array}$ \\
\hline SERANGAN & 1,00 & $0,007 \%$ & 2,01 & $2,473 \%$ & 2,12 & $0,284 \%$ \\
\hline SANUR & 1,10 & $0,008 \%$ & 2,21 & $2,585 \%$ & 2,53 & $0,339 \%$ \\
\hline BENOA & 14581,59 & $99,986 \%$ & 81,27 & $95,064 \%$ & 741,40 & $99,377 \%$ \\
\hline TOTAL & 14583,69 & $100,000 \%$ & 85,49 & $100,000 \%$ & 746,05 & $100,000 \%$ \\
\hline \multirow[t]{2}{*}{ PELABUHAN } & \multicolumn{6}{|c|}{ Gas Pencemar } \\
\hline & $\begin{array}{l}\text { Beban Emisi } \\
\text { (Ton/tahun) }\end{array}$ & $\begin{array}{l}\text { Persentase } \\
(\%)\end{array}$ & $\begin{array}{l}\text { Beban Emisi } \\
\text { (Ton/tahun) }\end{array}$ & $\begin{array}{c}\text { Persentase } \\
(\%)\end{array}$ & $\begin{array}{l}\text { Beban Emisi } \\
\text { (Ton/tahun) }\end{array}$ & $\begin{array}{c}\text { Persentase } \\
(\%)\end{array}$ \\
\hline SERANGAN & 0,01 & $0,002 \%$ & $57.615,18$ & $46,795 \%$ & $292.318,48$ & $20,051 \%$ \\
\hline SANUR & 0,01 & $0,002 \%$ & $63.388,93$ & $51,484 \%$ & $321.612,40$ & $22,060 \%$ \\
\hline BENOA & 503,51 & $99,997 \%$ & $2.119,47$ & $1,721 \%$ & $843.979,07$ & $57,890 \%$ \\
\hline TOTAL & 503,53 & $100,000 \%$ & $123.123,58$ & $100,000 \%$ & $1.457 .909,95$ & $100,000 \%$ \\
\hline
\end{tabular}

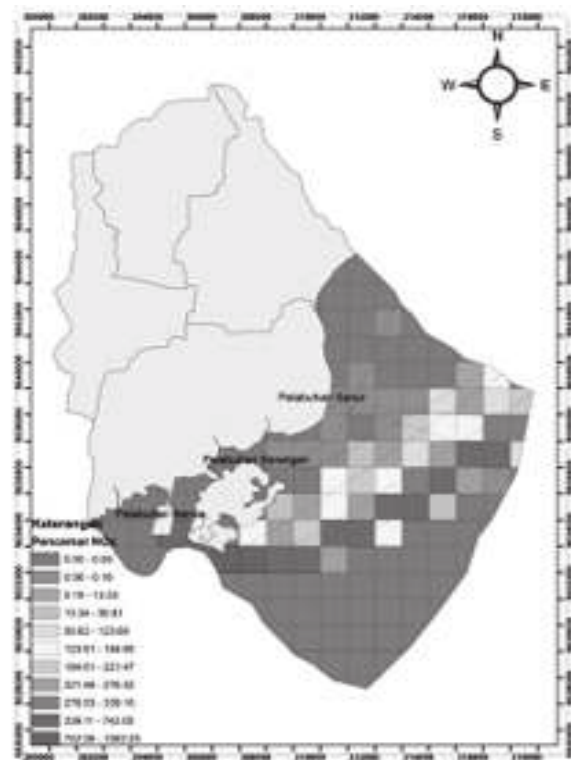

(a)

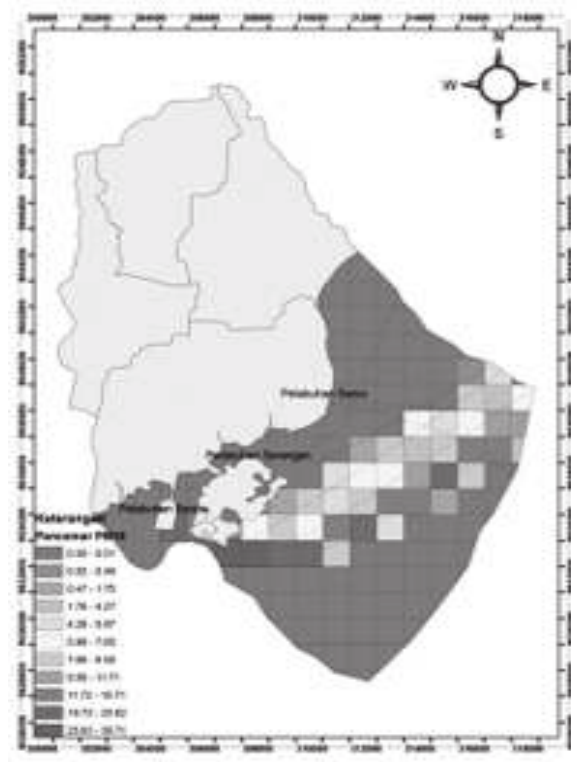

(d)

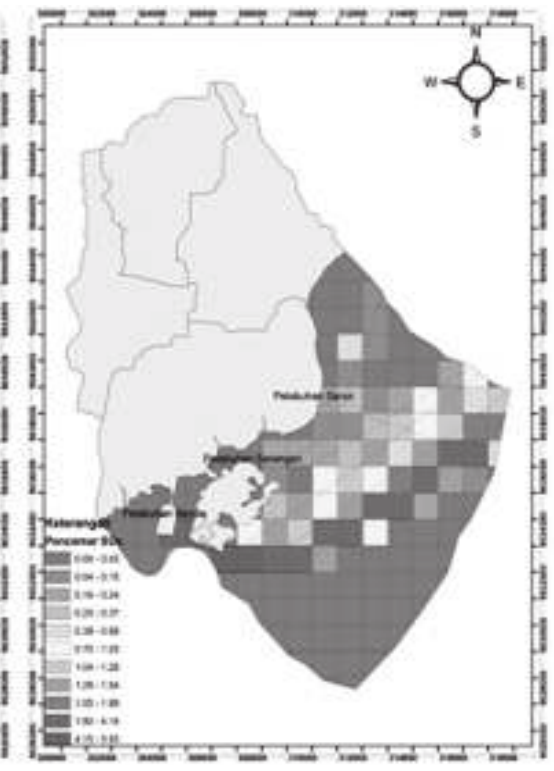

(b)

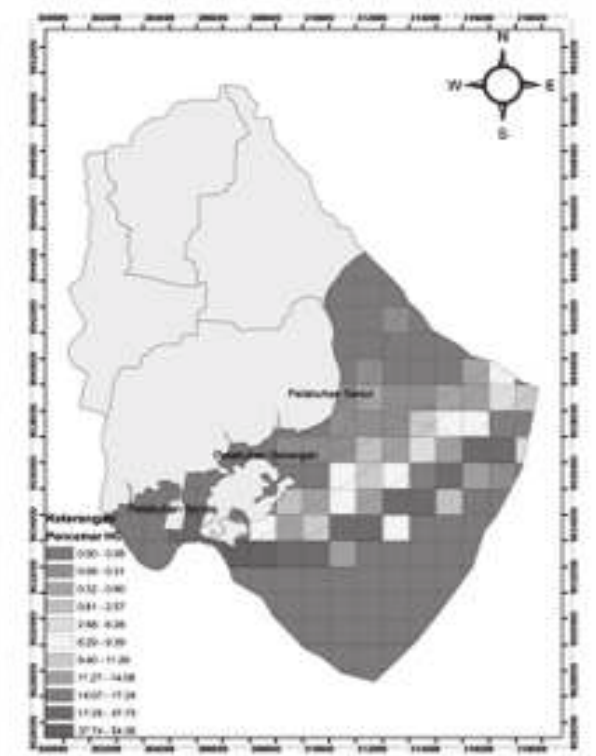

(c)

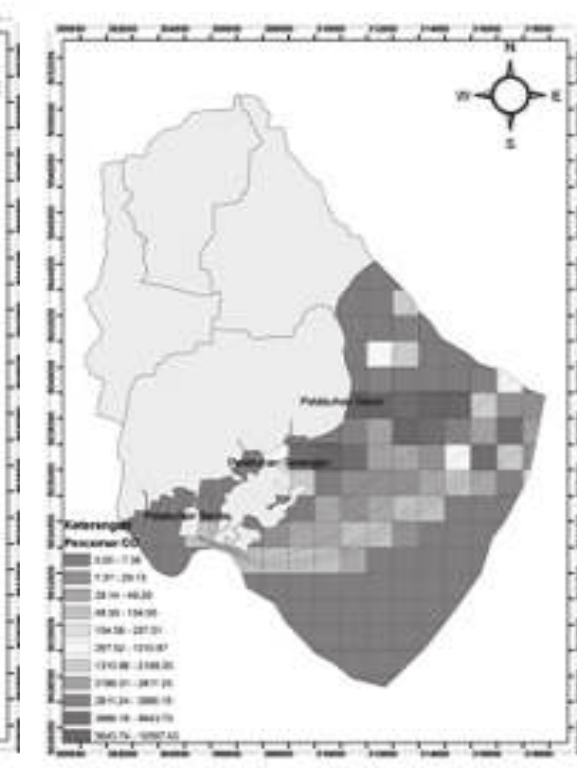

(e)

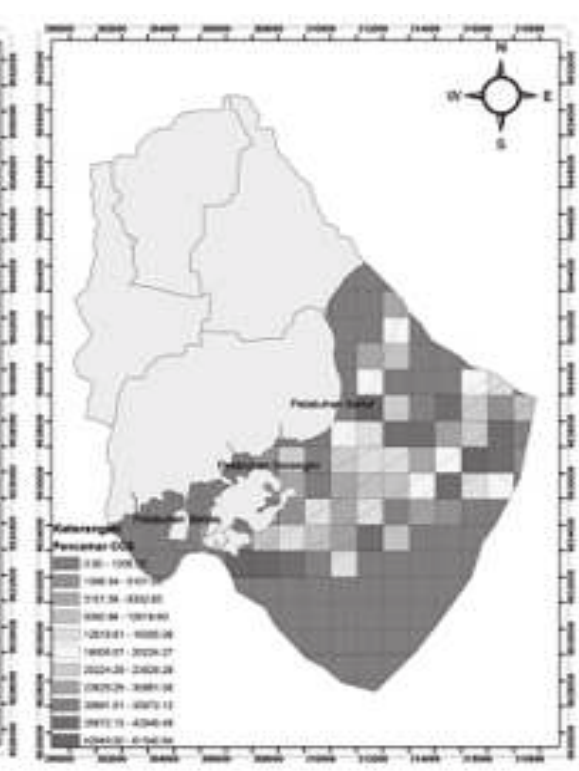

(f)

Gambar 2. Distribusi spasial dari sumber pencemar (a) $\mathrm{NO}_{x}$; (b) $\mathrm{SO}_{x}$; (c) $\mathrm{HC}$; (d) $\mathrm{PM}_{10}$ (e) $\mathrm{CO}_{\text {; }}$ (f) $\mathrm{CO}_{2}$ 
yaitu gradasi dari hijau ke merah terang sesuai dengan tingkat emisinya, semakin merah warna dalam peta maka akan semakin tinggi beban emisinya. Peta distribusi sebaran sumber pencemar $\mathrm{NO}_{\mathrm{x}}, \mathrm{SO}_{\mathrm{x}}, \mathrm{HC}, \mathrm{PM}_{10}, \mathrm{CO}$, dan $\mathrm{CO}_{2}$ dari Transportasi Laut di Kota Denpasar dapat dilihat pada Gambar 1.

\section{PEMBAHASAN}

\subsection{Beban Emisi Pencemar NO dari Transportasi Laut di Kota Denpasar}

Emisi pencemar $\mathrm{NO}_{\mathrm{x}}$ adalah sebesar 14.583,69 ton/tahun. Kegiatan Inventarisasi Emisi untuk sumber bergerak Non-Road juga dilakukan di Kota Palembang. Beban beban emisi untuk $\mathrm{NO}_{\mathrm{x}}$ di Kota Palembang adalah 217,51 ton/tahun. Nilai ini jauh lebih kecil dibandingkan dengan hasil penelitian untuk transportasi laut di Kota Denpasar. Hal ini disebabkan oleh adanya perbedaan lingkup penelitian dimana transportasi Non-Road yang diteliti oleh Kota Palembang adalah transportasi sungai yang banyak didominasi oleh jukung dan speed boat, sedangkan untuk Kota Denpasar, transportasi Non-Road yang diteliti adalah transportasi laut. Nilai $\mathrm{NO}_{\mathrm{x}}$ tertinggi dihasilkan oleh Pelabuhan Benoa. Beban emisi $\mathrm{NO}$ tertinggi dihasilkan oleh jenis kapal Passanger $(M D O)$ dan disusul oleh jenis kapal Fishing (MDO) yaitu sebesar 10.029,862 ton/tahun dan 3.995,811 ton/tahun. Sebagian besar kapal-kapal di Pelabuhan Benoa menggunakan mesin penggerak berupa mesin diesel. Mesin diesel merupakan sistem penggerak utama pada kapal (main engine). Mesin diesel masih menjadi pilihan utama bagi berbagai tipe kapal karena tingginya daya tahan efisiensi thermal, kemudahan dalam instalasi dan perawatan mesin (Santoso et al, 2006). Pelabuhan Serangan dan Pelabuhan Sanur hanya menyumbangkan emisi $\mathrm{NO}_{\mathrm{x}}$ dalam jumlah kecil yaitu sebesar 1,00 ton/tahun dan 1,10 ton/tahun. Jumlah ini jauh lebih kecil jika dibandingkan dengan jumlah emisi NO di Pelabuhan Benoa. Jenis kapal yang digunakan di Pelabuhan Serangan dan Pelabuhan Sanur didominasi oleh speed boat. Sistem penggerak speed boat menggunakan mesin tempel (outboard).

Komposisi $\mathrm{NO}_{\mathrm{x}}$ akan berubah-ubah dengan perubahan daya yang dihasilkan motor diesel.Pengaruh daya ini akan mengakibatkan perubahan suhu pada ruang bakar yang akanmempengaruhi jumlah oksigen bebas. Gas $\mathrm{NO}_{\mathrm{x}}$ yang dihasilkan dari pembakaran mesin diesel mengandung kelebihan oksigen. Tingginya konsentrasi oksigen di gas buang akan menyebabkan tingginya konsentrasi senyawa $\mathrm{NO}_{x}$. Senyawa $\mathrm{NO}_{x}$ ini sangat tidak stabil dan bila terlepas ke udara bebas, akan berikatan dengan oksigen untuk membentuk Nitrat oksida $\left(\mathrm{NO}_{2}\right)$. Gas ini sangat berbahaya karena senyawa ini amat beracun dan bila terkena air akan membentuk asam nitrat.

\subsection{Beban Emisi Pencemar SO dari Transportasi Laut di Kota Denpasar}

Emisi dari transportasi laut di Kota Denpasar menghasilkan gas pencemar $\mathrm{SO}_{\mathrm{x}}$ sebesar 85,49 ton/ tahun dimana Pelabuhan Benoa merupakan penyumbang terbesar yaitu sebesar 81,27 ton/tahun. Pelabuhan Serangan dan Pelabuhan Sanur memberikan kontribusi sebesar 2,01 ton/tahun dan 2,21 ton/tahun. Setyawan et al (2011) juga telah mengukur estimasi pencemaran udara dari sumber pencemar SO di daerah Shore Line Selat Madura yang menyatakan bahwa sebesar $758,45 \mathrm{~kg} / \mathrm{jam}$ gas $\mathrm{SO}_{2}$ dihasilkan oleh kapal berbendera Indonesia. Estimasi beban emisi $\mathrm{SO}_{\mathrm{x}}$ di Kota Palembang untuk transportasi sungai menghasilkan sekitar 8,25 ton/ tahun. Nilai ini jauh lebih kecil dibandingkan beban emisi dari transportasi laut di Kota Denpasar. Hal ini mungkin disebabkan tingginya lalu lintas kapal di Kota Denpasar yang mencapai 15.676 kapal, sedangkan lalu lintas kapal di Kota Palembang kurang dari 10.000 kapal (PPLH Universitas Sriwijaya, 2013).

Gas $\mathrm{SO}_{\mathrm{x}}$ merupakan salah satu emisi utama dari kendaraan bermotor dan angkutan barang seperti kapal laut. Pencemar $\mathrm{SO}_{\mathrm{x}}$ terbentuk dari kandungan Sulphur dalam bahan bakar yang terjadi selama proses pembakaran. Pembakaran pada mesin diesel dengan menggunakan bahan bakar fosil akan menghasilkan sulfur dioksida $\left(\mathrm{SO}_{2}\right)$ dan sulfur trioksida $\left(\mathrm{SO}_{3}\right)$ dengan perbandingan 30:1. Berarti, sulfur dioksida merupakan bagian yang sangat dominan dalam gas buang diesel.Saat dilakukan survey lapangan, tidak ditemukan asap (smog)di daerah sekitar Pelabuhan. Studi secara global menunjukkan bahwa daerah sekitar laut dan pelabuhan berkontribusi dalam pembentukan kabut asap fotokimia (photochemical smog) karena menghasilkan $\mathrm{NO}_{\mathrm{x}}$ dan $\mathrm{SO}_{\mathrm{x}}$. Kabut asap fotokimia menyebabkan peningkatan kadar ozon daan produksi senyawa organic yang berbahaya (Goldsworthy dan Galbally, 2011).

Emisi SOx di Pelabuhan Benoa cukup tinggi di Pelabuhan Benoa akan berpotensi terhadap fenomena hujan asam. Reaksi antara gas $\mathrm{SO}_{\mathrm{x}}$ dengan uap air yang terdapat diudara akan membentuk asam sulfat maupun asam sulfit. Apabila asam sulfat dan asam sulfit turun ke bumi bersama-sama dengan jatuhnya hujan,maka akan terjadi hujan asam. Hujan asam sangat merugikan karena dapat merusak tanaman maupun kesuburan tanah. Hutan yang gundul akibat jatuhnya hujan asam akan mengakibatkan lingkungan semakin parah (Pohan, 2002). 


\subsection{Beban Emisi Pencemar HC dari} Transportasi Laut di Kota Denpasar

Emisi pencemar HC (NMVOC) yang dihasilkan oleh transportasi laut di Kota Denpasar adalah sekitar 746,05 ton/tahun, yang dihasilkan di Pelabuhan Benoa yaitu sekitar 741,40 ton/tahun. Penelitian mengenai inventarisasi di Pelabuhan Yangsan, Shanghai menyatakan bahwa emisi HC yang didapatkan dari hasil perhitungan adalah 519,0 ton/tahun (Song, 2014). Nilai ini tidak berbeda jauh dengan nilai beban emisi di Kota Denpasar, karena dilihat dari lalu lintas kapalnya yang serupa. Selisih jumlah beban emisi di Pelabuhan Benoa dengan Pelabuhan Serangan dan Pelabuhan Sanur cukup signifikan. Hal ini mungkin dipengaruhi oleh jenis bahan bakar kapal di Pelabuhan Benoa yang banyak menggunakan bahan bakar solar.

\subsection{Beban Emisi Pencemar $P M_{10}$ dari Transportasi Laut di Kota Denpasar}

Total beban emisi $\mathrm{PM}_{10}$ yang dihasilkan oleh Kota Denpasar adalah 503,53 ton/tahun. Kapal-kapal yang beraktivitas di Pelabuhan Benoa menyumbangkan emisi terbesar yaitu 503,51 ton/ tahun, sedangkan Pelabuhan Serangan dan Sanur masing-masing hanya menyumbang 0,01 ton/tahun. Beban emisi $\mathrm{PM}_{10}$ didominasi oleh jenis kapal Passanger (MDO), Fishing (MDO) dan Tug Boat dengan nilai 371,226 ton/tahun, 115,245 ton/tahun dan 11,221 ton/tahun. Total beban emisi $\mathrm{PM}_{10}$ yang dihasilkan oleh sumber bergerak On-Road di Kota Denpasar adalah 444,16 ton/tahun (Purwanto, 2014). Berdasarkan data tersebut diketahui bahwa emisi $\mathrm{PM}_{10}$ lebih banyak dihasilkan oleh sumber bergerak Non-Road yang berasal dari transportasi laut. Kapal dengan mesin berbahan bakar solar lebih banyak menghasilkan $\mathrm{PM}_{10}$ dibandingkan dengan mesin berbahan bakar bensin. Emisi partikulat yang dihasilkan di Pelabuhan Benoa lebih besar daripada Pelabuhan Sanur dan Pelabuhan Serangan, yaitu 0,58 ton/tahun. Emisi partikulat yang dikeluarkan oleh mesin diesel ini sangat berbahaya dibandingkan dengan emisi yang dikeluarkan oleh mesin berbahan bakar bensin. Hal ini disebabkan oleh partikulat yang dikeluarkan oleh mesin diesel mempunyai kadar toksisitas relative paling tinggi, yaitu 106,7 (Nasikin et al., 2002).

Partikulat pada gas buang mesin diesel berasal dari partikel susunan bahan bakar yang masih berisikan kotoran kasar (abu, debu). Hal itu dikarenakan pemrosesan bahan bakarnya kurang baik.Bahan bakar diesel di Indonesia banyak mengandung kotoran, misalnya solar. Biasanya solar tidak berwarna atau bening, namun berwarna agak gelap yang menandakan adanya kotoran dalam bahan bakar.Dengan demikian, pada saat terjadi pembakaran, kotoran tersebut terurai dari susunan partikel yang lain dan tidak terbakar. Semakin banyak residu dalam bahan bakar akan dihasilkan gas buang dengan kepulan asap hitam.

\subsection{Beban Emisi Pencemar $\mathrm{CO}_{2}$ dari Transportasi Laut di Kota Denpasar}

Total beban emisi gas $\mathrm{CO}_{2}$ di Kota Denpasar adalah sebesar 1.457.909,95 ton/tahun. Beban emisi $\mathrm{CO}_{2}$ sebagian besar dihasilkan di Pelabuhan Benoa yaitu sebesar 843.979,07 ton/tahun, kemudian disusul oleh Pelabuhan Sanur sebesar 321.612,40 ton/tahun dan Pelabuhan Serangan menyumbang emisi $\mathrm{CO}_{2}$ paling sedikit yaitu 292.318,48 ton/tahun. Perbedaan beban emisi antara ketiga Pelabuhan tidak terlalu signifikan, meskipun jumlah lalu lintas kapal di Pelabuhan Benoa yang jauh lebih tinggi daripada Pelabuhan Sanur dan Pelabuhan Serangan. Hal ini mengindikasikan bahwa penggunaan mesin bensin, emisi $\mathrm{CO} 2$ yang dihasilkan lebih tinggi. Hal senada dinyatakan oleh Ismayanti et al. (2010) bahwa persentase sumber emisi $\mathrm{CO}_{2}$ terbesar di Kota Surabaya berasal dari bahan bakar bensin sebesar 63,36\% dan bahan bakar solar sebesar 23,64\%.

Pelabuhan Sanur dan Pelabuhan Serangan di Pelabuhan tempat beroperasinya speed boat yang melayani jasa transportasi antar pulau di sekitarnya, dimana speed boat ini menggunakan bahan bakar bensin. Pelabuhan Sanur dan Pelabuhan Serangan di Pelabuhan tempat beroperasinya speed boat yang melayani jasa transportasi antar pulau di sekitarnya. Speed boat dikendarai dengan kecepatan tinggi, dari survey di Pelabuhan Sanur dan Pelabuhan Serangan, diketahui rata-rata kecepatan speed boat berkisar antara 25 hingga 35 knot atau sekitar 46,3 hingga $64,8 \mathrm{~km} / \mathrm{jam}$. Kecepatan speed boat terkadang tidak stabil/konstan bergantung pada kondisi perairan. Kapal-kapal di Pelabuhan Benoa berlayar dengan kecepatan yang cukup stabil berkisar antara 7 hingga 14 knot atau senilai dengan 12,9 hingga $25,9 \mathrm{~km} /$ jam. Mesin diesel bekerja dengan kecepatan maksimum yang lebih rendah dibandingkandengan mesin bensin yang seringkalimempunyai kecepatan di atas 4.000 putaran per menit. Kebanyakan mesin diesel bekerja dengan kecepatan antara 50 sampai 2.500 putaran permenit. Mesin diesel yang bekerja dengan kecepatan putaran kurang dari 500 putaran permenit disebut mesin diesel dengan kecepatanputaran lambat, diatas 1.200 putaran permenit disebut mesin diesel kecepatan tinggi, sedangkan diantara keduanya disebut mesin dieselkecepatan sedang. Mesin diesel dengan kecepatan rendah digunakan sebagai mesinstationer dan digunakan di kapal-kapal besar (Aziz, 2010).

\subsection{Beban Emisi Pencemar CO dari Transportasi Laut di Kota Denpasar \\ Beban emisi CO dari transportasi laut di Kota Denpasar, didominasi oleh Pelabuhan Serangan dan Pelabuhan Sanur yaitu 57.615,18 ton/tahun dan}


63.388,93 ton/tahun, sedangkan Pelabuhan Benoa hanya menyumbang sekitar $2 \%$ yaitu $2.119,47$ ton/ tahun. Hal ini disebabkan adanya perbedaan bahan bakar yang digunakan di masing-masing Pelabuhan. Pelabuhan Serangan dan Sanur didominasi oleh speed boat dengan bahan bakar bensin, sebaliknya, kapal-kapal yang beraktivitas di Pelabuhan Benoa sebagian besar berbahan bakar solar. Banne (2011) menyatakan pada mesin diesel daya mesin yang dihasilkan sebesar 0,352 kW - 0,704 kw dengan kandungan $\mathrm{CO}$ 0,9 - 4,2\% sedangkan pada mesin bensin besarnya daya yang dihasilkan sebesar 0,308 kW - 1,465 kW. Bahan bakar solar menghasilkan konsentrasi gas CO yang lebih rendah dibandingkan dengan bahan bakar bensin. Jenis bahan pencemar yang dikeluarkan oleh mesin berbahan bakar bensin maupun berbahan bakar solar sebenarnya sama, perbedaan hanya terletak pada cara operasi mesin. Secara visual selalu terlihat asap hitam dari knalpot kendaraan berbahan bakar solar, yang umumnya tidak terlihat pada kendaraan berbahan bakar bensin (Hickman, 1999).Kenaikan kecepatan atau kenaikan putaran mesin juga dapat membentuk emisi CO. Hal ini disebabkan oleh adanya dominasi bahan bakar dalam ruang pembakaran sehingga sebahagian bahan bakar tidak terbakar menyebabkan terbentuknya CO pada gas buang. semakin besar daya yang diberikan semakin meningkatkan kadar CO.

4.7. Distribusi Sebaran Sumber Emisi Pencemar $\mathrm{NO}_{x}, \mathrm{SO}_{\mathrm{x}}, \mathrm{HC}, \mathrm{PM}_{10}, \mathrm{CO}$, dan $\mathrm{CO}_{2}$ dari Transportasi Laut di Kota Denpasar

Batas perairan Kota Denpasar kemudian divisualisasikan ke dalam GIS seperti yang ditunjukkan pada Gambar 2, kemudian rute kapal di masing-masing pelabuhan digambar sehingga dapat ditentukan rata-rata jarak tempuh kapal. Perhitungan jarak tempuh untuk kapal dari Pelabuhan Sanur adalah 7,53 km, sedangkan jarak tempuh kapal dari Pelabuhan Serangan adalah 9,16 $\mathrm{km}$. Pelabuhan Benoa memiliki lima alur kapal yang rata-rata memiliki jarak tempuh sekitar $14,82 \mathrm{~km}$. Beban emisi total dalam satu tahun dipetakan dengan menggunakan GIS. Peta spasial dibuat dengan memadukan data perhitungan dari excel dan GIS sehingga pada setiap selnya mengandung informasi mengenai beban emisi dari gas-gas pencemar $\mathrm{NO}_{\mathrm{x}}$, $\mathrm{SO}_{\mathrm{x}}, \mathrm{HC}, \mathrm{PM}_{10}, \mathrm{CO}$, dan $\mathrm{CO}_{2}$ seperti yang diperlihatkan pada Gambar 1.Beban emisi $\mathrm{NO}$, $\mathrm{SO}_{\mathrm{x}}$, $\mathrm{HC}$, dan $\mathrm{PM}_{10}$, cenderung identik, dimana sebagian besar terdistribusi di sekitar Pelabuhan Benoa, akan tetapi $\mathrm{CO}_{2}$ dan $\mathrm{CO}$ memiliki pola yang berbeda. Pola sebaran emisi $\mathrm{NO}_{\mathrm{x}}, \mathrm{SO}_{\mathrm{x}}, \mathrm{HC}$, dan $\mathrm{PM}_{10}$ dengan intensitas tertinggi mengikuti alur kapal-kapal dari Pelabuhan Benoa. Pola sebaran gas CO mengikuti alur kapal dari Pelabuhan Serangan menuju Manggis dan Gili Terawangan, serta dari Pelabuhan Sanur menuju Nusa Penida dan Nusa Lembongan. Pola sebaran gas $\mathrm{CO}_{2}$ hampir merata hampir di semua alur kapal baik dari Pelabuhan Serangan, Pelabuhan Sanur dan Pelabuhan Benoa dimana intensitas emisi tertinggi pada daerah sekitar Pelabuhan dan pada laut lepas. Warna merah pada Gambar 5.3-5.8 menunjukkan tingginya konsentrasi emisi gas pencemar. Secara keseluruhan, emisi gas pencemar dihasilkan paling tinggi di daerah sekitar pelabuhan. Hal ini terjadi karena padatnya lalu lintas di daerah tersebut, dimana terjadi arus keluar-masuknya kapal di Pelabuhan. Pada daerah ini terjadi kondisi maneuver dan hotelling dimana kapal mematikan mesin utamanya dan memaksimalkan beban daya pada mesin bantunya. Studi pemodelan menunjukkan bahwa emisi kapal kontribusi yang signifikan terhadap pencemaran di daerah terpencil wilayah laut, di sepanjang garis pantai, dan di pelabuhan (Skjølsvik et al, 2000).

Pencemaran udara di daerah pantai karena adanya aktivitas kapal di Pelabuhan dapat direduksi dengan berbagai upaya. Dua pilihan yang berpotensi paling efektif untuk mengurangi emisi dari kapal adalah shore power dan penggunaan bahan bakar rendah sulfur. Shore power atau shore supply adalah penyediaan tenaga listrik pada saat kapal parkir di dermaga sehingga kapal tidak perlu menyalakan mesin bantu untuk keperluan kelistrikan di kapal saat parkIr atau saat menurunkan muatan.Mengurangi bahan bakar yang mengandung sulfur tinggi dapat mereduksi emisi $\mathrm{SO}_{2}$. Di Uni Eropa sudah ditetapkan mandat untuk menggunakan bahan bakar dengan kadar sulfur 0,1 $\%$ atau dapat juga digunakan scrubber gas buang (exhaust gas scrubbers) untuk mencapai hasil yang sama (PAE Holmes, 2011). Scrubber adalah kumpulan alat pengendali polusi yang dapat membuang partikel dan/atau gas dari saluran pembuangan. Scrubber khusus untuk sistem EGR upstream (dipasang lebih dekat dengan mesin) dapat menangkap PM dengan efisiensi hingga 90\% dan pengambilan SOx hingga 70\% (IMarE, 2009).

Vessel Speed Reduction (VSR) adalah usaha untuk mengurangi kecepatan kapal dalam batas wilayah tertentu untuk mengurangi konsumsi bahan bakar sehingga emisi yang dihasilkan juga menurun. VSR juga telah diterapkan di Pelabuhan Los Angeles dan Pelabuhan Long Beach di California dengan menawarkan pengurangan biaya pelabuhan jika kapal mau mengurangi kecepatannya saat berlayar dalam batas 20 mil atau 40 mil dari pantai. Usaha ini mungkin diterapkan di Pelabuhan Sanur dan Serangan karena speed boat biasanya dikendarai dengan kecepatan yang cukup tinggi yang berpotensi menghasilkan emisi dalam jumlah yang cukup besar (PAE Holmes, 2011).Selain itu perlu dilakukan perawatan dan perbaikan secara berkala pada mesin kapal baik mesin diesel maupun mesin bensin mesin yang gunakan di kapal agar emisi yang dihasilkan oleh mesin kapal dapat direduksi sehingga tidak 
terjadi pencemaran udara yang dapat mengganggu kesehatan manusia dan merusak lingkungan sekitar.

\section{SIMPULAN DAN SARAN}

\subsection{Simpulan}

a. Total beban emisi dari pencemar $\mathrm{NO}_{\mathrm{x}}, \mathrm{SO}_{\mathrm{x}}, \mathrm{HC}$, $\mathrm{PM}_{10}$, CO, dan $\mathrm{CO}_{2}$ dari sumber bergerak NonRoad dari transportasi laut di Kota Denpasar secara beturut-turut adalah 14.583,69 ton/ tahun, 85,49 ton/tahun, 746,05 ton/tahun, 503,53 ton/tahun, $123.123,58$ ton/tahun dan 1.457.909,95 ton/tahun.

b. Total beban emisi yang dipetakan dengan GIS memperlihatkan bahwa beban emisi $\mathrm{NO}_{\mathrm{x}}, \mathrm{SO}_{\mathrm{x}}$, $\mathrm{HC}$ dan $\mathrm{PM}_{10}$ sebagian besar terdistribusi di sekitar Pelabuhan Benoa sedangkan beban emisi CO sebagian besar terdistribusi di Pelabuhan Sanur dan Serangan dan $\mathrm{CO}_{2}$ terdistribusi hampir merata di sepanjang alur kapal dari Pelabuhan Benoa dan alur kapal dari Pelabuhan Sanur menuju Nusa Penida dan Nusa Lembongan.

c. Perbedaan karakteristik transportasi laut di Pelabuhan Serangan, Pelabuhan Sanur dan Pelabuhan Benoa mempengaruhi karakteristik beban emisi pencemar $\mathrm{NO}_{\mathrm{x}}, \mathrm{SO}_{\mathrm{x}}, \mathrm{HC}, \mathrm{PM}_{10}, \mathrm{CO}$, dan $\mathrm{CO}_{2}$

\subsection{Saran}

a. Penelitian ini hanya mengambil model dari kapal-kapal yang telah teregistrasi di Pelabuhan Sanur, Pelabuhan Serangan dan Pelabuhan Benoa, namun belum dilakukan inventarisasi emisi sumber bergerak Non-road dari trasnportasi laut yang berasal dari kapal-kapal nelayan atau jukung yang beraktivitas di daerah tersebut.

b. Perlu dilakukan usaha-usaha dalam memantau emisi yang dihasilkan oleh transportasi laut dalam rangka meningkatkan kualitas udara dan mengurangi dampak negatif pencemaran udara.

\section{DAFTAR PUSTAKA}

Aziz, I. 2010. Uji Performance Mesin Diesel Menggunakan Biodiesel Dari Minyak Goreng Bekas. Skripsi. Program Studi Kimia Fakultas Sains dan Teknologi. UIN Syarif Hidayatullah. Jakarta.
Banne, MS. 2011. Analisis Kandungan Karbon Monoksida (CO) pada Mesin Diesel dan Bensin. ARIKA Vol. 05 No. 2.

Hickman, A.J., 1999. Methodology for Calculating Transport Emissions and Energy Consumption. Transport Research Laboratory.

IMarE. 2009. IMarE Review. Jakarta

Kementerian Lingkungan Hidup. 2013. Pedoman Teknis Penyusunan Inventarisasi Emisi Pencemar Udara di Perkotaan.

PAE Holmes. 2011. Potential Measures for Air Emissions From NSW Ports : Preliminary Study.NSW Office of Environment and Heritage.

Purwanto, C.P. 2014. Inventarisasi Emisi Sumber Bergerak di Jalan (On-Road) Kota Denpasar. Tesis. Program Studi Ilmu Lingkungan. Universitas Udayana.

Pusat Penelitian Lingkungan Hidup Universitas Sriwijaya. 2013. Emission Inventory for the City of Palembang South Sumatra - Indonesia.

Santoso, A. 2006. LNG Carrier. Buletin Marine Engineer. Vol. XXX. Hal. 17-20

Saraçoðlu, H., Cengiz D,. Alper K. 2013. An Investigation on the Effects of Ship Sourced Emissions in Izmir Port, Turkey. The Scientific World Journal Vol. 2013.

Skjølsvik, K.O., A.B. Andersen, J.J. Corbett, dan J.M. Skjelvik. 2000. Study of Greenhouse Gas Emissions from Ships (MEPC 45/8 Report to International Maritime Organization on the outcome of the IMO Study on Greenhouse Gas Emissions from Ships). MARINTEK Sintef Group. Carnegie Mellon University. Center for Economic Analysis, and Det Norske Veritas. Trondheim. Norway.

Song, S. 2014. Ship Emissions Inventory, Social Cost and Eco-Efficiency in Shanghai Yangshan Port. Atmospheric Environment Vol. 82 Page 288-297.

Trozzi, C., Riccardo D.L. 2013. 1.A.3.d Navigation (Shipping) GB2013.CORINAIREmission Inventory Guidebook. 